\title{
PERANCANGAN PEMBANGKIT TEGANGAN TINGGI IMPULS EKSPONENSIAL GANDA RANGKAIAN R-C
}

\author{
Dwaldes Bernad*), Abdul Syakur, dan Agung Warsito \\ Departemen Teknik Elektro, Universitas Diponegoro \\ Jl. Prof. Sudharto, SH, Kampus UNDIP Tembalang, Semarang 50275, Indonesia \\ ${ }^{*}$ E-mail:dwaldesb@gmail.com
}

\begin{abstract}
Abstrak
Pembangkitan tegangan tinggi saat ini sudah sangat berkembang di Indonesia. Sudah banyak sekali peralatan-peralatan yang menggunakan spesifikasi tegangan tinggi. Dengan adanya peralatan tegangan tinggi ini maka diperlukan juga isolasi tegangan tinggi dalam setiap perangkatnya. Salah satu metode pengujian isolasi tegangan tinggi adalah dengan menggunakan tegangan tinggi impuls. Pada Tugas Akhir ini dirancang pembangkit tegangan tinggi impuls exponensial ganda rangkaian R-C sehingga dapat menghasilkan tegangan impuls petir yang sesuai standar. Standar yang berisi tentang gelombang keluaran impuls adalah IEC 60060-1. Purwarupa yang dibuat semakin sederhana dan lebih mudah dalam pengoperasiannya. Sehingga dalam pengujian, seorang penguji dapat melakukannya dengan lebih aman dan efisien. Diharapkan gelombang keluaran dari rancangan ini sudah sesuai dengan standar tersebut. Gelombang impuls yang memenuhi standar adalah gelombang yang memiliki waktu muka sebesar 1,2 $\mu$ s dengan toleransi sebesar $\pm 30 \%$. Lalu yang diharapkan dari waktu ekornya adalah sebesar $50 \mu$ s dengan toleransi yaitu $\pm 20 \%$. Dari hasil pengujian yang dilakukan nilai waktu ekor yang diperoleh hanya sekitar $23 \mu$ s hingga $29 \mu$ s. Nilai ini belum sesuai dengan standarnya. Oleh karena itu pengujian ini masih bisa diperbaiki kedepannya untuk memperbaiki waktu ekor agar dapat sesuai dengan standar yang diharapkan.
\end{abstract}

Kata Kunci: tegangan tinggi impuls, Rangkaian R-C, standar IEC 60060-1, waktu muka, waktu ekor.

\begin{abstract}
High voltage generation is currently very developed in Indonesia. There are a lot of equipment that uses high voltage specifications. With this high voltage equipment, high voltage isolation is needed in each device. One method of testing high voltage insulation is to use high voltage impulses. In this Final Project designed high voltage dual exponential impulse R-C circuit so that it can produce lightning impulse voltage according to the standard. The standard that contains the impulse output wave is IEC 60060-1. The prototype is made simpler and easier to operate. So that in testing, a tester can do it more safely and efficiently. It is expected that the output wave from this design is in accordance with these standards. Impulse waves that meet the standard are waves that have a face time of $1.2 \mu$ s with a tolerance of $\pm 30 \%$. Then what is expected from the tail time is $50 \mu$ s with a tolerance of $\pm 20 \%$. From the test results, the tail time value obtained was only around $23 \mu$ s to $29 \mu \mathrm{s}$. This value is not in accordance with the standard. Therefore, this test can still be improved in the future to improve the tail time so that it can be in accordance with the expected standards.
\end{abstract}

Keywords: high impulse voltage, $R-C$ circuit, IEC 60060-1 standard, face time, tail time.

\section{Pendahuluan}

Saat ini, tegangan tinggi semakin banyak digunakan dalam kehidupan. Pada umumnya tegangan tinggi digunakan untuk keperluan transmisi tenaga listrik, penelitian dan pengujian tegangan tinggi di laboratorium. Pembangkit tegangan tinggi terdiri atas pembangkit tegangan tinggi $\mathrm{AC}$, pembangkit tegangan tinggi $\mathrm{DC}$, dan pembangkit tegangan tinggi impuls [1]. Tegangan impuls merupakan gelombang tegangan dengan karakteristik yang unik. Tegangan yang dihasilkan pada gelombang impuls yaitu tegangan yang naik pesat mencapai nilai tertentu kemudian jatuh menuju nilai nol. Pada umumnya tegangan tinggi impuls dibangkitkan untuk keperluan pengujian isolasi suatu sistem. Untuk keperluan tersebut, tegangan tinggi impuls yang dibangkitkan harus memenuhi standar tertentu. Menurut standar IEC 60060-1, tegangan impuls yang diperlukan untuk pengujian isolasi memiliki waktu muka $1,2 \mu \mathrm{s}$ dan waktu ekor $50 \mu \mathrm{s}$. Toleransi yang diperbolehkan adalah $20 \%$ untuk waktu ekor dan $30 \%$ untuk waktu muka.

Menurut Rifky Nurmansyah, penambahan komponen Rs, ditujukan untuk menahan arus pengisian kapasitor. Setelah dilakukan pengujian ternyata tidak ada perubahan yang 
signifikan pada setiap parameternya antara menggunakan Rs maupun tanpa menggunakan Rs. Hal ini dikarenakan trafo uji yang digunakan pada saat pengujian memiliki rating arus pada sisi sekunder yang relative sangat kecil, jadi tanpa melakukan penambahan komponen Rs sudah didapatkan hasil gelombang seperti yang diinginkan [2].

Pada penelitian sebelumnya, beliau menguji variasi resistor pengisian pada rangkaian R-C. Untuk penelitian lebih lanjut, penulis akan menguji variasi resistor pengukuran pada rangkaian $\mathrm{R}-\mathrm{C}$ untuk lebih mengetahui dampak variasi tersebut terhadap karakteristik gelombang impuls yang dihasilkan.

Pada skala laboratorium, tegangan tinggi impuls dihasilkan untuk penelitian dan pengujian. Pembangkitan tegangan impuls dapat dilakukan dengan menggunakan rangkaian $\mathrm{R}-\mathrm{C}$ [3]. Rangkaian R-C merupakan kombinasi resistor dan juga kapasitor yang dirangkai sehingga membentuk rangkaian pembangkit tegangan tinggi impuls. Keluaran dari rangkaian R-C merupakan gelombang eksponensial ganda yang berbentuk menyerupai tegangan impuls [4]. Nilai-nilai dari komponen penyusunan rangkaian akan menentukan bentuk gelombang keluaran yang dihasilkan. Perangkat keras yang direalisasikan akan digunakan sebagai modul praktikum di Laboratorium Konversi Energi Listrik dan Sistem Tenaga.

Pada tugas akhir ini akan dirancang rangkaian pembangkitan tegangan tinggi impuls eksponensial ganda berbasis rangkaian $\mathrm{R}-\mathrm{C}$ dengan 2 macam topologi. Variasi akan dilakukan pada besarnya kapasitor keluaran dan juga pada jarak sela pada elektroda. Masing-masing rangkaian akan disusun sehingga dapat menghasilkan impuls petir. Kemudian, gelombang keluaran yang dihasilkan akan dibandingkan dengan satu sama lain menurut variasi yang akan dilakukan. Gelombang keluaran yang dihasilkan diharapkan mampu menghasilkan tegangan impuls yang sesuai dengan standar IEC 60060-1[5].

Adapun tujuan utama dari pembuatan tugas akhir ini adalah sebagai berikut:

1. Merancang dan membuat modul pembangkit tegangan tinggi impuls yang akan dimanfaatkan untuk modul praktikum di Laboratorium Konversi Energi Listrik dan Sistem Tenaga.

2. Mengetahui pengaruh topologi yang digunakan melalui analisis terhadap nilai tegangan keluaran pada rangkaian pengujian pembangkit tegangan tinggi impuls.

3. Mengetahui pengaruh jarak sela yang digunakan pada elektroda terhadap tegangan saat terjadinya impuls.

4. Mengetahui variabel resistor pengisian terhadap nilai waktu muka dan waktu ekor pada rangkaian pengujian pembangkit tegangan tinggi impuls.

\section{Metode}

\subsection{Perancangan Perangkat Keras (Hardware)}

Perancangan perangkat keras terdiri dari rangkaian sumber tegangan arus bolak - balik 1 fasa, rangkaian pembangkit tegangan tinggi arus searah dan rangkaian pembangkit tegangan tinggi impuls. Diagram blok perangkat keras yang dirancang pada tugas akhir ini ditunjukkan pada Gambar 1.

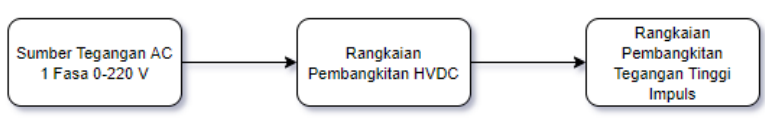

\section{Gambar 1. Diagram Blok Perangkat Keras}

Spesifikasi perangkat keras yang telah dirancang pada tugas akhir ini berdasarkan Gambar 1. adalah sebagai berikut :

1. Sumber tegangan arus bolak - balik 1 Fasa sebagai sumber tegangan masukan untuk rangkaian pembangkitan tegangan tinggi arus searah dengan menggunakan regulator tegangan.

2. Rangkaian pembangkitan tegangan tinggi arus searah digunakan untuk menghasilkan tegangan tinggi arus searah yang akan menjadi suplai bagi blok rangkaian pembangkitan tegangan tinggi impuls.

3. Rangkaian pembangkitan tegangan tinggi impuls sebagai pembentuk gelombang impuls.

\subsubsection{Sumber Tegangan Arus Bolak-Balik 1 Fasa}

Suplai tegangan arus bolak - balik 1 fasa berasal dari jalajala PLN dengan tegangan $220 \mathrm{~V}$ Line to Netral dengan frekuensi $50 \mathrm{~Hz}$ seperti Gambar 3.3.

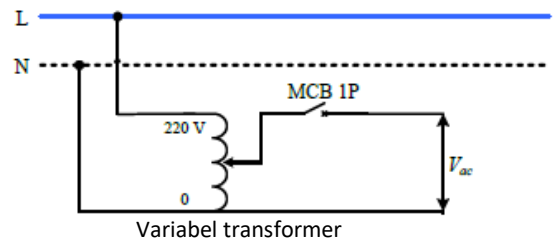

Gambar 2. Rangkaian Suplai Tegangan 1 Fasa

Variabel transformator digunakan untuk memvariasikan tegangan. Variabel transformator yang digunakan memiliki spesifikasi tegangan keluaran maksimal $250 \mathrm{~V}$ dengan arus maksimal 5 A. Sumber tegangan arus bolak balik satu fasa digunakan sebagai sumber tegangan untuk mensuplai rangkaian pembangkit tegangan tinggi arus searah. 
Kemudian tegangan jala-jala dihubungkan dengan sign transformer dengan perbandingan $220 \mathrm{~V} \mathrm{/} 15000 \mathrm{~V}$. Sehingga diperoleh pehitungan sebagai berikut.

$$
\text { Vout }=\frac{\text { Vin }}{220 \mathrm{~V}} * 15000 \mathrm{~V}
$$

Dari persamaan di atas maka akan diperoleh tegangan tinggi arus bolak-balik. Tegangan tinggi arus bolak-balik yang merupakan tegangan dengan gelombang sinusoidal.

\subsubsection{Pembangkitan Tegangan Tinggi Arus Searah}

Pada penelitian ini digunakan rangkaian penyearah setengah gelombang dengan tegangan output akan dibatasi pada nilai $14 \mathrm{kV}$. Gambar 3 menunjukan rangkaian penyearah setengah gelombang. Pada rangkaian digunakan sebuah diode tegangan tinggi. Sumber tegangan tinggi arus bolak - balik 1 fasa yang digunakan diperoleh dari trafo uji yang terhubung dengan variabel transformer.

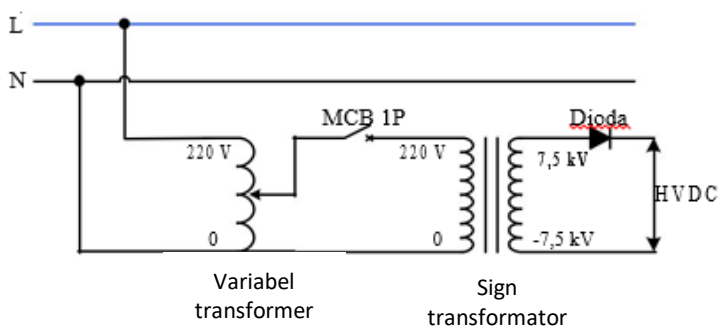

Gambar 3. Rangkaian Pembangkit Tegangan Tinggi Arus Searah

\subsubsection{Pembangkitan Tegangan Tinggi Impuls}

Pembangkitan Tegangan tinggi impuls dapat dihasilkan melalui berbagai topologi. Pada penelitian ini akan dibahas dan dibuat rangkaian pembangkit tegangan tinggi impuls topologi B dan topologi C [3]. Gambar 4 dan Gambar 5 merupakan rangkaian yang akan direalisasikan menjadi perangkat keras. Masing-masing rangkaian terdiri dari blok sumber tegangan tinggi arus searah dan blok pembentuk gelombang tegangan tinggi impuls.

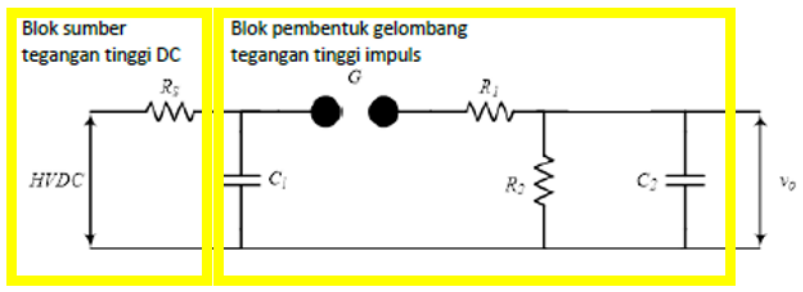

Gambar 4. Topologi B

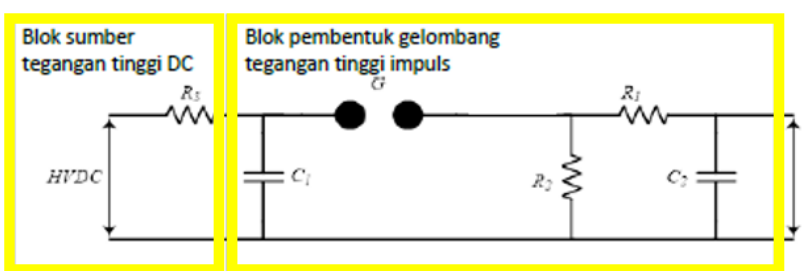

Gambar 5. Topologi C

Pada blok sumber tegangan tinggi arus searah terdapat Rs yang merupakan tahanan pengisian. Rs berfungsi untuk membatasi muatan dari sumber tegangan tinggi arus searah supaya tidak mengisi kapasitor pengisian saat breakdown yang terjadi pada sela udara $\mathrm{G}$.

Tegangan impuls yang dibangkitkan adalah tegangan impuls petir yang sesuai dengan standar IEC 60060-1, yaitu memiliki waktu muka (tf) 1,2 $\mu$ s dan waktu ekor (tt) $50 \mu \mathrm{s}$. Berdasarkan teori bahwa nilai rangkaian R-C bisa menghasilkan impuls ketika nilai $\mathrm{C} 1$ lebih besar dari nilai C2. Dari teori itu maka ditetapkan nilai variasi yang digunakan pada penelitian ini yaitu pada kapasitor keluaran sebesar $4,7 \mathrm{nF}, 2,35 \mathrm{nF}$, dan 1,56 $\mathrm{nF}$ dengan perbandingan waktu muka dan waktu ekor sebesar $1,2 / 50 \mu$ s, sedangkan nilai resistornya akan didapatkan melalui perhitungan. Sedangkan untuk nilai C1 sendiri merupakan nilai tetap yaitu sebesar 9,4 $\mathrm{nF}$.

\subsection{Menentukan Nilai Komponen Rangkaian Pembangkitan Tegangan Tinggi Impuls}

2.2.1. Perhitungan Nilai Komponen Rangkaian Pembangkit Tegangan Impuls R-C

A. Perhitungan Nilai R1 dan R2 pada topologi B

Perhitungan pada rangkaian R-C dengan nilai $\mathrm{C} 1=9,4 \mathrm{nF}$, $\mathrm{C} 2=4,7 \mathrm{nF}, \alpha=6,4$ dan $\theta=5,26 \mu \mathrm{s}$.

$$
\begin{aligned}
& X=\frac{1}{\alpha^{2}}\left(1+\frac{C 1}{C 2}\right) \\
& X=\frac{1}{6,4^{2}}\left(1+\frac{9,4 \cdot 10^{-9}}{4,7 \cdot 10^{-9}}\right) \\
& X=0,0732
\end{aligned}
$$

Perhitungan nilai R1 dengan menggunakan Persamaan

$$
\begin{aligned}
& \mathrm{R} 1=\frac{\alpha \theta}{\mathrm{C} 1}(1-\sqrt{1-\mathrm{X})} \\
& \mathrm{R} 1=\frac{6,4.5,26 \cdot 10^{\wedge}-6}{9,4 \cdot 10^{\wedge}-9}(1-\sqrt{1-0,0732)} \\
& \mathrm{R} 1=133,5654
\end{aligned}
$$


Perhitungan nilai R2 dengan menggunakan Persamaan

$$
\begin{aligned}
& \mathrm{R} 2=\frac{\alpha \theta}{\mathrm{C} 1+\mathrm{C} 2}(1+\sqrt{1-\mathrm{X})} \\
& \mathrm{R} 2=\frac{6,4.5,26.10^{-6}}{9,4.10^{-9}+4,7 \cdot 10^{-9}}(1+\sqrt{1-0,0732)} \\
& \mathrm{R} 2=4685,991
\end{aligned}
$$

Dengan menggunakan cara yang sama seperti perhitungan diatas, diperoleh hasil perhitungan $R 1$ dan $R 2$ menggunakan nilai kapasitor keluaran $2,35 \mathrm{nF}$ dan $1,56 \mathrm{nF}$ pada Tabel 1.

Tabel 1. Hasil perhitungan komponen R1 dan R2 topologi B berdasarkan referensi [3]

\begin{tabular}{ccc}
\hline $\boldsymbol{C 1}(\boldsymbol{n F})$ & $\boldsymbol{R} 1(\Omega)$ & $R \mathbf{2}(\Omega)$ \\
\hline 4,7 & 133,5654 & 4865,991 \\
2,35 & 225,943 & 5549,302 \\
1,56 & 321,527 & 5867,302 \\
\hline
\end{tabular}

B. Perhitungan Nilai R1 dan R2 pada Topologi C

Perhitungan pada rangkaian $\mathrm{R}-\mathrm{C}$ dengan nilai $\mathrm{C} 1=9,4 \mathrm{nF}$, $\mathrm{C} 2=4,7 \mathrm{nF}, \alpha=6,4$ dan $\theta=5,26 \mu \mathrm{s}$.

Perhitungan dengan persamaan berdasarkan referensi [3] Perhitungan nilai $X$ dengan menggunakan Persamaan

$X=\frac{1}{\alpha^{2}}\left(1+\frac{C 1}{C 2}\right)$

$X=\frac{1}{6,4^{2}}\left(1+\frac{9,4 \cdot 10^{-9}}{4,7 \cdot 10^{-9}}\right)$

$X=0,0732$

Perhitungan nilai $R l$ dengan menggunakan Persamaan

$\mathrm{R} 1=\frac{\alpha \theta}{\mathrm{C} 1}(1-\sqrt{1-\mathrm{X})}$

$\mathrm{R} 1=\frac{6,4 \cdot 5,26 \cdot 10^{-6}}{4,7 \cdot 10^{-9}}(1-\sqrt{1-0,0732)}$

$\mathrm{R} 1=267,130$

Perhitungan nilai R2 dengan menggunakan Persamaan

$$
\begin{aligned}
\mathrm{R} 2 & =\frac{\alpha \theta}{\mathrm{C} 1+\mathrm{C} 2}(1+\sqrt{1-\mathrm{X})} \\
\mathrm{R} 2 & =\frac{6,4 \cdot 5,26 \cdot 10^{-6}}{9,4 \cdot 10^{-9}+4,7 \cdot 10^{-9}}(1+\sqrt{1-0,0732)} \\
\mathrm{R} 2 & =4685,991
\end{aligned}
$$

Dengan menggunakan cara yang sama seperti perhitungan diatas, diperoleh hasil perhitungan $R 1$ dan $R 2$ menggunakan nilai kapasitor keluaran $2,35 \mathrm{nF}$ dan $1,56 \mathrm{nF}$ pada Tabel 2.

Tabel 2. Hasil perhitungan komponen R1 dan R2 topologi C berdasarkan referensi [3]

\begin{tabular}{ccc}
\hline$C 1(n F)$ & $R 1(\Omega)$ & $R 2(\Omega)$ \\
\hline 4,7 & 267,130 & 4865,991 \\
2,35 & 902,782 & 5549,302 \\
1,56 & 3342,595 & 5867,302 \\
\hline
\end{tabular}

\section{Hasil dan Analisis}

3.1. Pengujian dengan Jarak Sela $1,5 \mathrm{~mm}$ dan $3 \mathrm{~mm}$ 3.1.1. Pengujian jarak sela $1,5 \mathrm{~mm}$

Pengujian ini bertujuan untuk mengetahui variasi kapasitor pengukuran terhadap keluaran rangkaian pembangkit tegangan impuls. Lalu akan dianalisa perbandingan gelombang keluaran antara rangkaian pembangkit tegangan impuls topologi B dan topologi $\mathrm{C}$ pada jarak sela yang tetap.

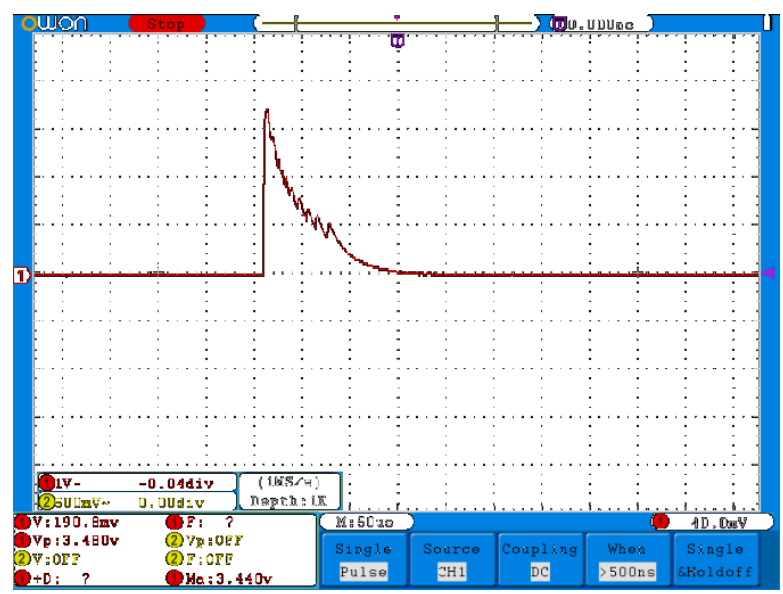

Gambar 6 . Gelombang keluaran tegangan impuls dengan jarak sela $1,5 \mathrm{~mm}$ dan kapasitor pengukuran 4,7 nF pada topologi $B$

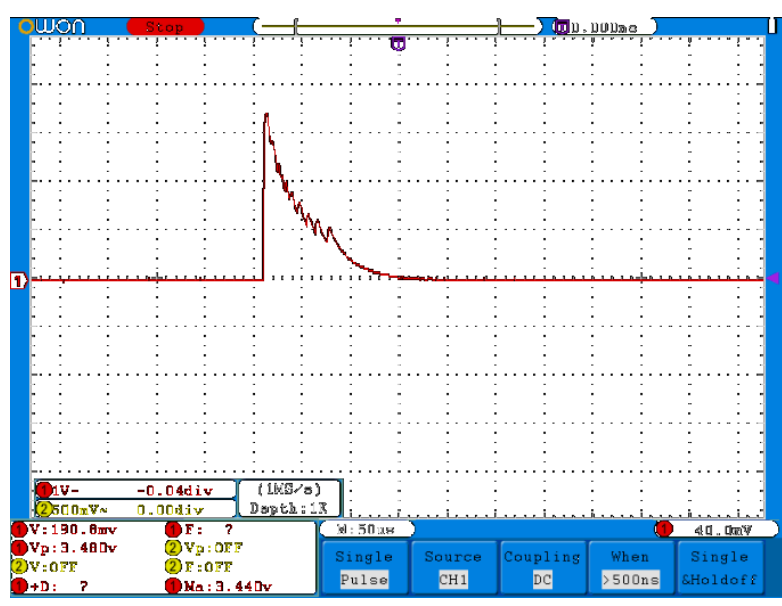

Gambar 7. Gelombang keluaran tegangan impuls dengan jarak sela 1,5 mm dan kapasitor pengukuran 4,7 $\mathrm{nF}$ pada tolopogi $\mathrm{C}$

Gambar 6 dan Gambar 7 adalah gelombang keluaran tegangan impuls yang dihasilkan dari rangkaian pengujian. Dalam pengujian juga dilakukan variasi nilai kapasitor pengukuran yaitu sebesar $4,7 \mathrm{nF}, 2,35 \mathrm{nF}$, dan $1,56 \mathrm{nF}$ pada Data hasil pengujian ditampilkan pada Tabel 3.

Berdasarkan Tabel 3 didapatkan perbandingan data hasil pengujian dimana pada tegangan masukan arus searah yang relatif sama, pada topologi $\mathrm{C}$ menghasilkan tegangan 
keluaran yang lebih besar daripada topologi B. Nilai waktu muka pada variasi kapasitor pengukuran topologi B masih dianggap sesuai karena masih terdapat dalam batas toleransi yaitu sebesar $\pm 30 \%$. sedangkan untuk variasi kapasitor pengukuran topologi $\mathrm{C}$, nilai yang sesuai dengan batas toleransi hanya berlaku pada variasi $4,7 \mathrm{nF}$ saja. Variasi kapasitor pengukuran 2,35 $\mathrm{nF}$ dan 1,56 $\mathrm{nF}$ masih sangat jauh dengan nilai yang diinginkan $( \pm 30 \%$ dari 1,2 $\mu \mathrm{s})$. Hal ini dikarenakan nilai resistor pembentuk gelombang yang digunakan pada variasi kapasitor pengukuran 2,35 $\mathrm{nF}$ dan 1,56 topologi $\mathrm{C}$ dirasa kurang sesuai dengan perhitungan resistor, karena nilainya yang cukup tinggi jika dibandingkan dengan nilai yang terdapat pada variasi kapasitor pengukuran 4,7 nF. Nilai waktu ekor yang dihasilkan pada kedua topologi belum sesuai dengan waktu yang diinginkan $( \pm 20 \%$ dari $50 \mu \mathrm{s})$, yaitu pada kisaran $25 \mu \mathrm{s}-26,15 \mu \mathrm{s}$. Keadaan ini dapat disebabkan oleh berbagai hal, Adanya VCR (Voltage Coefficient of Resistance) pada resistor yang digunakan, sehingga nilai resistansi akan cenderung berkurang pada tegangan tinggi. Adanya kapasitansi pada sela udara yang digunakan, sehingga kemungkinan akan menyebabkan kapasitansi pengisian akan berkurang nilainya.

Tabel 3. Perbandingan antara topologi $B$ dan topologi $C$ pada jarak sela $1,5 \mathrm{~mm}$

\begin{tabular}{ccccccc}
\hline Topologi & $C_{2}(\mathrm{nF})$ & $\operatorname{Vin}(\mathrm{V})$ & $V D C(\mathrm{kV})$ & $\operatorname{Vmax}(\mathrm{kV})$ & $t f(\mu \mathrm{s})$ & $t t(\mu \mathrm{s})$ \\
\hline \multirow{3}{*}{$\mathrm{B}$} & 4,7 & 94,4 & 6,19 & 7,2 & 1,440 & 26,367 \\
& 2,35 & 95,4 & 6,24 & 7,4 & 1,041 & 24,994 \\
& 1,56 & 96,16 & 6,33 & 7,5 & 1,418 & 24,927 \\
\hline \multirow{2}{*}{$\mathrm{C}$} & 4,7 & 94,8 & 6,20 & 7,2 & 1,485 & 25,038 \\
& 2,35 & 98 & 6,24 & 7,8 & 2,349 & 29,611 \\
& 1,56 & 99,7 & 6,33 & 8,0 & 2,947 & 28,029 \\
\hline
\end{tabular}

\subsubsection{Pengujian jarak sela $3 \mathrm{~mm}$}

Pengujian ini bertujuan untuk mengetahui pengaruh variasi kapasitor terhadap gelombang keluaran rangkaian pembangkit tegangan impuls. Kemudian akan dianalisis pula perbandingan gelombang keluaran antara rangkaian pembangkit tegangan impuls topologi $\mathrm{B}$ dan topologi $\mathrm{C}$ pada jarak sela yang tetap.

Gambar 8 dan Gambar 9 adalah gelombang keluaran tegangan impuls yang dihasilkan dari rangkaian pengujian. Dalam pengujian juga dilakukan variasi nilai kapasitor pengisian yaitu sebesar 4,7 nF, 2,35 nF, dan 1,56 nF. Data hasil pengujian ditampilkan pada Tabel 4.

Tabel 4. Perbandingan antara topologi $B$ dan topologi $C$ pada jarak sela $3 \mathrm{~mm}$

\begin{tabular}{ccccccc}
\hline Topologi & $C_{2}(\mathrm{nF})$ & $V i n(\mathrm{~V})$ & $V D C(\mathrm{kV})$ & $V \max (\mathrm{kV})$ & $t f(\mu \mathrm{s})$ & $t t(\mu \mathrm{s})$ \\
\hline \multirow{3}{*}{$\mathrm{B}$} & 4,7 & 131,3 & 8,49 & 10,6 & 0,968 & 26,478 \\
& 2,35 & 131,4 & 8,51 & 10,6 & 0,952 & 31,685 \\
& 1,56 & 132,4 & 8,55 & 10,7 & 0,912 & 36,892 \\
\hline \multirow{3}{*}{ C } & 4,7 & 134,43 & 8,91 & 10,6 & 1,485 & 26,146 \\
& 2,35 & 137,87 & 9,05 & 10,7 & 2,264 & 34,122 \\
& 1,56 & 138,62 & 9,11 & 10,8 & 1,972 & 33,901 \\
\hline
\end{tabular}

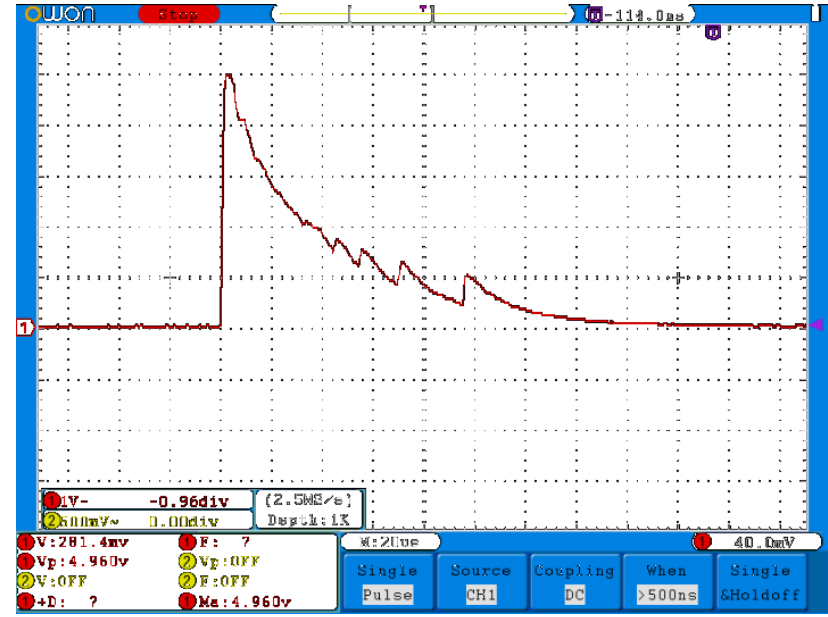

Gambar 8 . Gelombang keluaran tegangan impuls dengan jarak sela $3 \mathrm{~mm}$ dan kapasitor pengukuran 4,7 nF pada topologi $B$

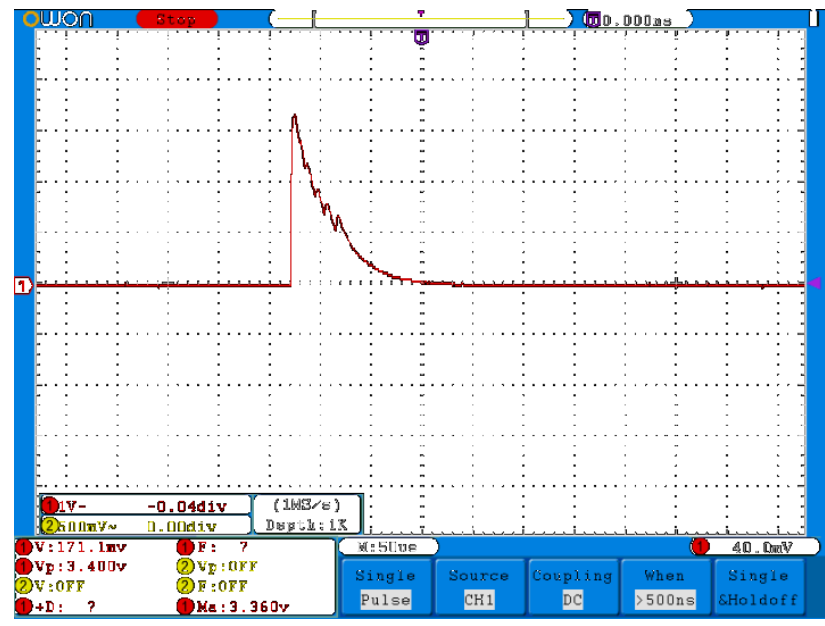

Gambar 9. Gelombang keluaran tegangan impuls dengan jarak sela $3 \mathrm{~mm}$ dan kapasitor pengukuran 4,7 nF pada topologi $C$

Berdasarkan Tabel 4 didapatkan perbandingan data hasil pengujian dimana pada tegangan masukan arus searah yang relatif sama, pada topologi $\mathrm{C}$ menghasilkan tegangan keluaran yang lebih besar daripada topologi B. Nilai waktu muka pada variasi kapasitor pengukuran topologi B masih dianggap sesuai karena masih terdapat dalam batas toleransi yaitu sebesar $\pm 30 \%$. sedangkan untuk variasi kapasitor pengukuran topologi $\mathrm{C}$, nilai yang sesuai dengan batas toleransi hanya berlaku pada variasi $4,7 \mathrm{nF}$ saja. Variasi kapasitor pengukuran 2,35 $\mathrm{nF}$ dan 1,56 $\mathrm{nF}$ masih sangat jauh dengan nilai yang diinginkan $( \pm 30 \%$ dari 1,2 $\mu \mathrm{s})$. Hal ini dikarenakan nilai resistor pembentuk gelombang yang digunakan pada variasi kapasitor pengukuran 2,35 $\mathrm{nF}$ dan 1,56 topologi $\mathrm{C}$ dirasa kurang sesuai dengan perhitungan resistor, karena nilainya yang cukup tinggi jika dibandingkan dengan nilai yang terdapat pada variasi kapasitor pengukuran $4,7 \mathrm{nF}$. Nilai waktu ekor yang dihasilkan pada kedua topologi belum sesuai dengan 
waktu yang diinginkan $( \pm 20 \%$ dari $50 \mu \mathrm{s})$, yaitu pada kisaran $26 \mu \mathrm{s}-36 \mu \mathrm{s}$. Keadaan ini dapat disebabkan oleh berbagai hal, Adanya VCR (Voltage Coefficient of Resistance) pada resistor yang digunakan, sehingga nilai resistansi akan cenderung berkurang pada tegangan tinggi. Adanya kapasitansi pada sela udara yang digunakan, sehingga kemungkinan akan menyebabkan kapasitansi pengisian akan berkurang nilainya.

\subsection{Membandingkan Jarak Sela $1,5 \mathrm{~mm}$ dengan 3,0 mm pada topologi $B$}

Pengujian dengan membandingkan jarak antara topologi B pada jarak sela $1,5 \mathrm{~mm}$ dan juga $3,0 \mathrm{~mm}$ dilakukan untuk mengetahui pengaruh jarak sela terhadap tegangan yang dibutuhkan untuk menghasilkan tegangan impuls.

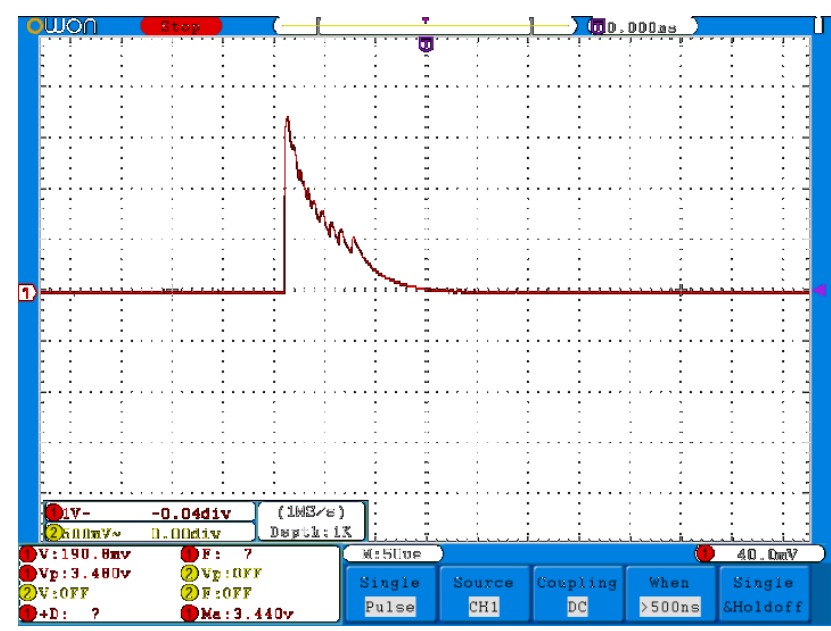

Gambar 10. Gelombang keluaran tegangan impuls dengan jarak sela 1,5 mm dan kapasitor pengukuran 4,7 nF pada topologi $B$

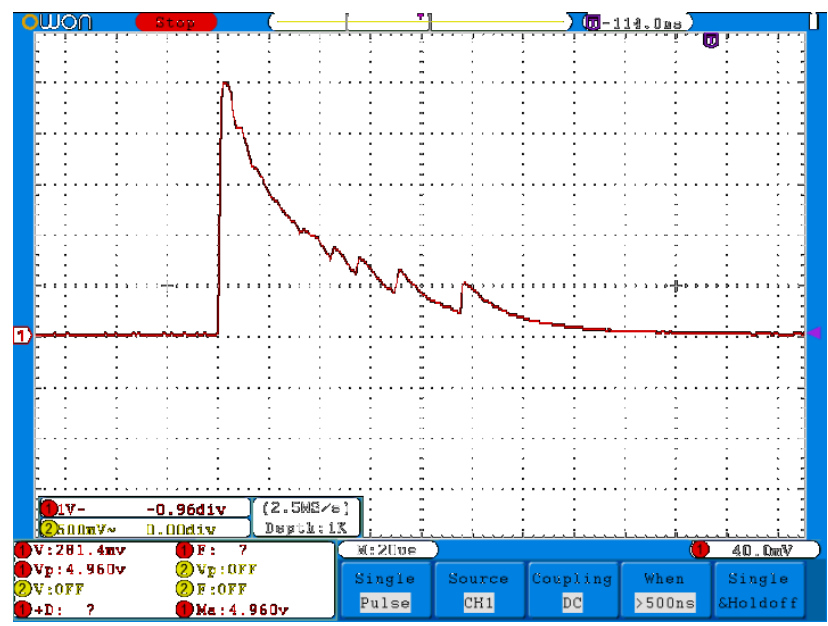

Gambar 11. Gelombang keluaran tegangan impuls dengan jarak sela 1,5 mm dan kapasitor pengukuran 4,7 nF pada topologi $B$
Berdasarkan pengujian yang dilakukan dengan memvariasi nilai jarak sela yaitu $1,5 \mathrm{~mm}$ dan juga $3 \mathrm{~mm}$ pada topologi yang sama. Dalam pengujian ini diambil contoh untuk menggunakan topologi B untuk dibandingkan, maka dihasilkan nilai nilai yang tertera dalam tabel 5 .

Tabel 5. Perbandingan jarak sela pada topologi B

\begin{tabular}{ccccccc}
\hline $\begin{array}{c}\text { Jarak } \\
\text { Sela }\end{array}$ & $C_{2}(\mathrm{nF})$ & $V i n(\mathrm{~V})$ & $V D(\mathrm{kV})$ & $V \max (\mathrm{kV})$ & $t f(\mu \mathrm{s})$ & $t t(\mu \mathrm{s})$ \\
\hline \multirow{3}{*}{$1,5 \mathrm{~mm}$} & 4,7 & 94,4 & 6,19 & 7,2 & 1,440 & 26,367 \\
& 2,35 & 95,4 & 6,24 & 7,4 & 1,041 & 24,994 \\
& 1,56 & 96,16 & 6,33 & 7,5 & 1,418 & 24,927 \\
\hline \multirow{3}{*}{$3 \mathrm{~mm}$} & 4,7 & 131,3 & 8,49 & 10,6 & 0,968 & 26,478 \\
& 2,35 & 131,4 & 8,51 & 10,6 & 0,952 & 31,685 \\
& 1,56 & 132,4 & 8,55 & 10,7 & 0,912 & 36,892 \\
\hline
\end{tabular}

Dari pengujian di atas dapat dilihat bahwa tegangan yang dibutuhkan untuk menghasilkan impuls antara jarak 1,5 $\mathrm{mm}$ dan juga $3 \mathrm{~mm}$ terlihat sangat berbeda. Pada jarak sela $3 \mathrm{~mm}$ tegangan impuls dapat timbul pada tegangan antara $10,6 \mathrm{kV}-10,7 \mathrm{kV}$. Sedangkan pada jarak $1,5 \mathrm{~mm}$ tegangan impuls yang timbul sebesar 7,2 kV - 7,5 kV. Untuk waktu muka dan waktu ekor yang dihasilkan juga dapat terlihat perbedaannya. Pada saat jarak sela 1,5 , waktu muka yang dihasilkan melebihi $1 \mu$ s sedangkan saat jarak sela $3 \mathrm{~mm}$ yang waktu muka yang dihasilkan pada gelombang tidak sampai $1 \mu$ s. Namun keduanya masih sesuai dengan standar IEC 60060-1 yang mana waktu muka yang terjadi pada impuls adalah senilai $1,2 \mu$ s dengan toleransi $\pm 30 \%$. Namun untuk waktu ekornya, keduanya masih tidak ada yang memenuhi jumlah hingga $50 \mu \mathrm{s}$.

\subsection{Pengujian dengan dan tanpa resistor pengisian}

Pengujian ini dilakukan untuk membandingkan pembangkit tegangan impul dengan dan tanpa menggunakan resistor pengisian. Diambil percobaan menggunakan jarak sela tetap $1,5 \mathrm{~mm}$ dan dengan topologi B.

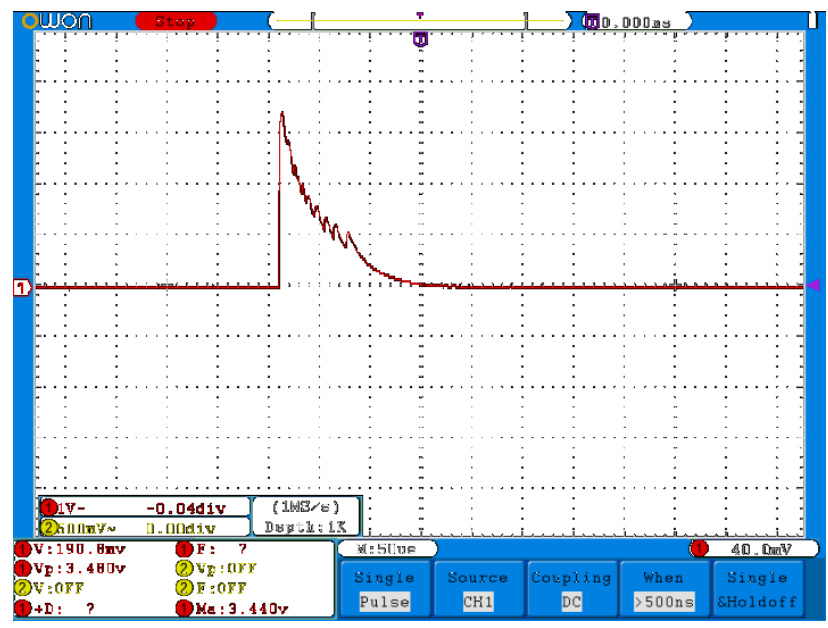

Gambar 12. Gelombang keluaran tegangan impuls jarak sela $1,5 \mathrm{~mm}$ dan kapasitor pengukuran 4,7 $\mathrm{nF}$ tanpa resistor pengisian 


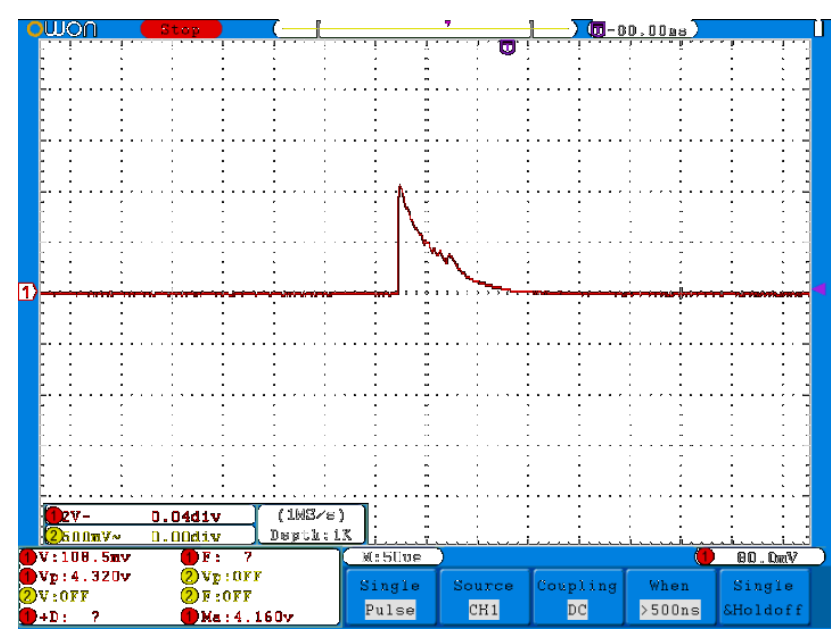

Gambar 13. Gelombang keluaran tegangan impuls jarak sela $1,5 \mathrm{~mm}$ dan kapasitor pengukuran $4,7 \mathrm{nF}$ dengan resistor pengisian

Dari percobaan yang sama hingga variasi kapasitor pengukuran 2,35 $\mathrm{nF}$ dan $1,56 \mathrm{nF}$ maka diperoleh data pada tabel 6.

Tabel 6. Perbandingan dengan dan tanpa resistor pengisian

\begin{tabular}{ccccccc}
\hline$C_{2}(\mathrm{nF})$ & $\mathrm{Rs}$ & $\operatorname{Vin}(\mathrm{V})$ & $V D C(\mathrm{kV})$ & $\operatorname{Vmax}(\mathrm{kV})$ & $t f(\mu \mathrm{s})$ & $t t(\mu \mathrm{s})$ \\
\hline 4,7 & & 94,7 & 6,21 & 7,3 & 1,219 & 24,706 \\
2,35 & \multirow{2}{*}{0} & 95,2 & 6,23 & 7,4 & 1,485 & 26,589 \\
1,56 & & 95,9 & 6,26 & 7,8 & 1,728 & 23,376 \\
\hline 4,7 & & 96,8 & 6,19 & 7,6 & 1,485 & 26,921 \\
2,35 & \multirow{2}{*}{$\mathrm{k}$} & 97,2 & 6,20 & 7,7 & 2,742 & 27,364 \\
1,56 & & 99,3 & 6,29 & 7,9 & 3,058 & 29,802 \\
\hline
\end{tabular}

Pada pengujian tegangan tinggi impuls dengan dan tanpa menggunakan resistor pengisian (Rs) tidak begitu ada dampak yang signifikan karena fungsi dari resistor pengisian ini hanya ditujukan untuk menahan arus pengisian kapasitor. Hal ini dikarenakan arus sekunder yang dihasilkan dari sign transformer relatif sangat kecil.

\section{Kesimpulan}

Berdasarkan pengujian dan analisis yang dilakukan pada perancangan pembangkit tegangan tinggi impuls eksponensial ganda rangkaian $\mathrm{RC}$ telah berhasil dibuat dengan membandingkan 2 buah topologi rangkaian yang ada, yaitu topoogi B dan topologi C. Pada topologi B dengan jarak sela 1,5 mm adalah sebesar 7,2-7,5 kV. Pada topologi $\mathrm{C}$ dengan jarak sela $1,5 \mathrm{~mm}$ dihasilkan tegangan tinggi impuls sebesar 7,2 -8,0 kV. Tegangan keluaran impuls bersifat fluktuatif seiring dilakukannya variasi nilai kapasitor pengukuran.

Pada jarak sela yang berbeda, semakin jauh jarak sela yang digunakan maka akan semakin besar juga tegangan DC masukan yang dibutuhkan untuk menghasilkan tegangan tinggi impuls. Hal ini dibuktikan dengan percobaan pada saat jarak sela 1,5 mm dan $3 \mathrm{~mm}$, dimana pada saat 1,5 mm tegangan impuls yang dihasilkan sebesar 7-8 kV sedangkan pada saat jarak sela $3 \mathrm{~mm}$ tegangan impuls yang dihasilkan sekitar 10,5-10,8 kV.

Pengaruh yang terjadi akibat memvariasi kapasitor pengisian terhadap pengujian pembangkit impuls dengan variasi kapasitor pengukuran memiliki dampak yang hampir sama. Hal ini karena berkaitan dengan acuan refrensi yang digunakan oleh penulis.

\section{Referensi}

[1]. Tobing, Bonggas L, Dasar Teknik Pengujian Tegangan Tinggi, Penerbit PT Gramedia Pustaka Utama, Jakarta, 2003.

[2]. Nurmansyah, Rifky, "Unjuk Kerja Modul Pembangkit Impuls Eksponensial Ganda Berbasis Rangkaian R-C". Laporan Penelitian, Universitas Diponegoro. 2016.

[3]. Salam, Mazen Abdel, dkk, "High Voltage Engineering Theory and Practice" Second Edition, Revised, expanded, Marcel Dekker, Basel, 2000.

[4]. Bimatara, Tofan. "Kinerja Rangkaian R-C dan R-L-C dalam Pembangkitan Tegangan Tinggi Impuls". Laporan Penelitian, Universitas Diponegoro. 2016.

[5]. IEC 60060-1: "High Voltage Test Techniques, Part 1, General Definition and Test Techniques", Geneva (1994)

[6]. Aguet, Michel. Ianoz, Michel. "Traite d'Electricite" Volume XXII.

[7]. Kuffel, E, dkk, "High Voltage Engineering: Fundamentals", Second Edition, Butterworth Heinemann, Oxford. 2000.

[8]. Kind, Dieter, Pengantar Teknik Eksperimental Tegangan Tinggi. Bandung,. Indonesia: ITB, 1993. 